\title{
The Evaluation of School-Parent Association Activities According to the Views of the Teachers ${ }^{i}$
}

\author{
Bilgen Kiral", Yusuf Gidis \\ Department of Educational Administration, Faculty of Education, Aydin Adnan Menderes University, Turkey
}

Copyright@2019 by authors, all rights reserved. Authors agree that this article remains permanently open access under the terms of the Creative Commons Attribution License 4.0 International License

\begin{abstract}
This research aims to evaluate the activities of School-Parent Association (SPA) in Turkey according to the teachers' views. The study was conducted with 10 volunteer teachers who participated in the activities of SPA in two public Anatolian high schools in Turgutlu district of Manisa province in Turkey in 2017-2018 academic year. The results of the research show that the teachers have little knowledge about SPA members. The duties of SPA are identified as generating monetary resources for teachers, school and students in need, organising social activities to increase student achievement and improving physical conditions of the school. The results show that the work of SPA is seen as inefficient and the middle-income parents who have successful children with no disciplinary problem usually attend SPA meetings. The reasons for low participation in SPA are expressed as its responsibilities and the financial contribution expected from parents during meetings. Some of the suggestions which were determined to participate the SPA, to increase to parent participation are increasing communication, addressing prejudices, explaining the importance of SPA to all stakeholders of the school, including parents in management meetings, supporting a legal legislation that appreciates work of teachers and parents, organising family/ home visits and reaching out parents through phones or text messages.
\end{abstract}

Keywords School-Parent Association (SPA), Teacher, Anatolian High School, Meeting

\section{Introduction}

Schools are organizations established to serve the education and development needs of societies. The process of education, which starts with the family, continues with schools and plays an important role in shaping the society. Since the school exists in the community, it must communicate and cooperate with the family, individuals and institutions in society.
Schools are established to provide social development and they have the purpose of educating both individuals and society whilst cooperating with the surrounding environment [30]. School organizations, which have cooperation, communication and interaction with the outer world, are defined as open systems [49]. Open systems support the interaction with the environment and respond to external influences to seek support. Open system theory in education requires a relationship between institutions and families, and external groups such as employers and local education authorities $[2,7]$.

Open system organizations affect their environment and are also affected by their environment. Therefore, they cannot be considered separately from the school environment. Establishing a good organisation is directly related to the existence of a good environment [50]. Can [8, 9] states that school-family cooperation is more important in lower grades of education such as primary school. Successful education at primary level can be achieved through a healthy, continuous and strong cooperation between schools and the families. Communication, interaction and ties between schools and the families need to be very strong for the benefit of society, environment, family and the individual. School-Parent Association (SPA) is key for this relationship [30]. This strong parent-school collaboration increases the communication between parents and teachers, eliminates barriers to children's development, and brings family and school resources together to achieve shared goals [11]

The SPA was introduced on 02-10 December 1946 by the Minister of National Education, Resat Semsettin Sirer. For the first time, it was decided to introduce the principles of education and training to the families and SPA became a part of education [37] The legal infrastructure of the SPA was prepared by the Ministry of National Education. The Regulation of the SPA [39] was enacted and the article 5 of this Regulation defines the roles and responsibilities of SPAs. This article states that the association was established in order to ease the integration between schools and the families, enhance communication and cooperation 
between parents and schools, support the activities that promote education, and meet the compulsory needs of the students who do not have financial means. The associations take the name of the school in which it was founded such as the Merzifon Cumhuriyet Elementary School SPA, Aydin Ataturk High School SPA. Article 6 of outlines the duties of the association. These are to contribute to school and student development by organizing educational, artistic, sportive, literary, cultural and social facilities in cooperation with the administrators, teachers, parents and families [39].

The 16th article of the National Education Basic Law, which constitutes the Turkish Education System, also addresses SPAs and their duties. This article states that the cooperation between schools and families is essential to contribute to the realization of the aims of the educational institutions. SPAs established in line with this purpose aims to bring efficiency to the education and training services of schools, accepts the donations of kind and cash to meet the needs of the students without financial means, organizes social and cultural activities and campaigns and to operate space, canteen, saloon of schools in order to create income for the school [38].

In short, SPA is a mechanism for establishing an effective link between schools and families. It aims to strengthen the relationships between these constituencies and provide cooperation between parents and teachers in the process of raising students [45]. Likewise, the article 6 of the Regulation of School-Parent Association [39] states the role of association is "to cooperate with the school management, teachers, parents and families in order to educate the students in line with the general and specific objectives of the Turkish national education and the basic principles and national spiritual values. "It is among the duties of the union to inform the school regularly about education, to provide parents with school support and to contribute to the school's activities [8]. There are many factors inside and outside the school which play a role in the school achievement of students. Family is one of the primary outside school factors.

Families are key to the academic achievement of their children, especially the quality of the communication they will establish with their children and the level of cooperation with the school is essential for achievement [3, 23]. Family participation increases student achievement, and voluntary activities carried out by families improve student performance [22].

The purposes of the school can be achieved only if schools and families have shared goals and the actions of these two institutions are in line with those goals. Therefore, it is necessary to understand the aims of the school, create an atmosphere of trust between the school and the family, accept the leadership of the school, ensure that the students are consulted about the school, and establish a healthy communication between schools and the families [33]. The
Basic Law of National Education Numbered 1739 [38] states that "cooperation between the school and the family is important to contribute to the realization of the objectives of the educational institutions. The SPAs are established to serve this purpose." These associations play an important role in meeting the objectives of National Education.

The collaboration of SPA positively affects the student achievement and psychology [40, 50] Establishing a good communication and cooperation between parents and teachers at primary school is vital for students' life [21]. Such a collaboration is essential in supporting students' academic, social and emotion development and plays a mediating role in school achievement [44]. Another significant benefit of the association is to ensure that students develop democratic culture. To create a democratic culture at school, parents should also be included in the system [26]. This is because family is the first education institution for children and the values learned here are strengthened at schools [29]. Martin, Tett and Kay [34] argues that a good parent and school collaboration can develop the awareness of participation and active citizenship among students and families. The school principals, teachers and other stakeholders at school should adopt democracy, human rights and freedoms. It is not enough to believe in these values, but one should also perform these in their everyday life. This necessitates the cooperation between stakeholders working at school, parents and the environment [16].

Dogru [17] lists the aims of SPAs as follows; (a) preventing educational conflicts between the school and parents, (b) ensuring communication and collaboration with institutions outside the school and supporting the education of students (c) informing parents with regard to development and needs of their children (d) organising events to increase student achievement (e) benefiting from the knowledge, skills and experiences of parents for better education facilities (f) organising activities that could bond school, teachers and parents, (g) organising facilities for students' health and education both at home and at school, (h) supporting legislations that aim to protect the children and youth, (i) increasing the collaboration between school and family (j) planning activities to meet students' mental, social and psychological needs $(\mathrm{k})$ providing resources for school facilities (l) supporting teachers' education, research and resource expenses, (m) establishing, developing and taking care of the facilities at school, (n) supporting school's managerial and educational activities.

The research shows that children of parents who are regularly in touch with schools show higher academic achievement [14]; families can contribute to education by organising complementary facilities to schooling of their children [3]; families influence the school environment positively [26]; participation of families in school activities increase the school achievement of the student [15], and 
quality education can be provided through family participation [19].

As the literature suggests, establishing strong links between schools and parents and sustainability of these links will also increase the efficiency of school. This research aims to explore teachers' views on parent-teacher associations and seeks to answer following research questions:

1) What are the duties of the SPAs according to the teachers?

2) What are the view of teachers regarding the effectiveness of the work of SPA?

3) What are the views of teachers about the profile of parents who participated in SPA meetings?

4) What are the views of parents with regard to participation of parents in SPA and efforts of increasing parental participation?

5) What are the suggestions to make SPA more effective?

\section{Materials and Methods}

The research employs qualitative case study research design. The qualitative research approach was chosen to work on deeper and more detailed, study fewer participants and situations, and provides more and more detailed information [43]. A case study requires the investigation and description of a specific situation within the current environment in the real world $[12,35]$. The case in this study is SPA and its efficiency. It is aimed to describe the opinions of teachers about the work of SPA.

\subsection{Participants}

Participants of this research are teachers who work actively in the teacher-parent association in two public Anatolian high schools in Turgutlu district of Manisa in Turkey province during 2017-2018 academic year. Convenient sampling is used to recruit participants. Both schools have middle-income socio-economic level. The reason for preference of Anatolian high schools in the scope of the research is to reveal the understanding about the work of SPAs in high schools and to describe them according to the opinions of the teachers. In addition to convenient sampling, teachers with an experience of over 10 years and over 40-year-old were chosen, and thus criterion sampling was also used for recruitment of participants. The reason for these criteria is that these teachers would have the opportunity to have observed the work of School-Parent Association over the years and they can more easily describe and interpret the work done in such associations [51]. Table 1 shows the teachers' information.

Table 1. Teachers' information

\begin{tabular}{cccccc}
\hline Teachers' code names & Gender & Age & Branch & Seniority & Seniority in the same school \\
\hline Ali & Male & 43 & Turkish Literature & 19 & 4 \\
Ahmet & Male & 49 & History & 22 & 11 \\
Mehmet & Male & 47 & Philosophy & 17 & 6 \\
Salih & Male & 40 & Geography & 17 & 9 \\
Elmas & Female & 40 & Geography & 18 & 10 \\
Yusuf & Male & 51 & History & 27 & 10 \\
Bilgen & Female & 44 & Physical Education & 22 & 16 \\
Ecesu & Female & 43 & Counseling & 11 & 4 \\
Erkan & Male & 41 & Geography & 17 & 1 \\
Ilke & Female & 43 & Turkish Literature & 21 & 2 \\
\hline
\end{tabular}

In Table 1 as could be seen, six male and four female teachers with more than 10 years of experiences and aged between 40 and 51 participated in the study. They were teaching in the following fields: literature, history, geography, philosophy, and physical education. Teachers of science and maths did not take part in the study, as these teachers did not play an active role in the SPAs. 


\subsection{Data Collection and Analysis}

Semi-structured interviews were used to collect data. After the interview form was given to two faculty members for the validity of the scope, a pilot research was carried out. The form was revised after the pilot research. The semi-structured interview form consists questions that aim to elicit teachers' opinions about the work of the SPA, the profile of the parents participating in SPAs, the effectiveness of the work and the teachers' suggestions to improve the activities of the SPA. The participants were assured of confidentiality before the research took place. Face-to-face interviews were conducted in teachers' room, canteens or labs. The interviews were recorded, and the length of recordings ranged between 13 and 35 minutes with an average interview length of 17 minutes. The interviews were transcribed, and the transcripts are 20-page long. Content analysis was used to analyse the data, and then categories and sub-categories are formed [51]

The participants' opinions were included in the study without any change and with direct quotations to ensure validity $[43,51]$. At the end of the research, the transcripts were handed into the participants for confirmation and they were asked if there was anything else they wanted to add. The formula of Miles and Huberman [36] were used to ensure reliability in the study, and the reliability rate was calculated as $92 \%$, which shows that the study is reliable. Pseudonyms are used in the research. The study aligned with the ethical codes and principles and integrity of doing research.

\section{Findings}

This section presents the findings of the research as "the work of spa members, the efficiency of spa, the profile of parents on spa, teachers' views about increasing participation of parents to spa, the suggestions to make spa more active and effective"

\subsection{The Duties of SPA Members}

The fact that teachers are not able to say exactly who the members of the SPA are means they are not interested in their work. Teachers were also asked about the work of the SPA and Table 2 presents their responses.

- $\quad$ The members of the SPA are parents, the principal and the vice-principal (Ecesu).

- $\quad S P A$ is the name of the union formed by parents, teachers and school principals. The members of this association consist of teachers, principals, parents and students (Ali)

As seen in Table 2, the work done by SPA can be grouped under four categories: economic, social, achievement and meeting the needs of school. Economic category includes providing resource to get flowers and refreshments on teachers' day, generating income for students and financially helping students. Social category includes end of year trips, organising charity events or campaigns and doing work that could contribute to development school. The achievement category includes work to be done to increase student achievement and school facilities. The last category of meeting needs is about meeting physical needs of schools such as repairs, improving physical environment, cleaning etc. Quotations are provided below:

- SPA buys us flowers and offers us lunch and refreshment on teachers 'day. I do not remember them generating income for the families or helping out students financially (Ali)

- The work of SPA aims at meeting the needs of school because school expenses such as electricity, water and heating are being met by the state. However, cleaning materials, repairs or broken windows are not funded by the state. SPA usually funds such expenses (Salih)

- $\quad$ SPA work to make our school better, improve quality of education, improve the physical conditions of our school (Bilge).

- $\quad$ SPA members come to school whenever there is a campaign or an event organisation. I don't think they are engaged with any activities that could improve education quality (Erkan)

Table 2. The duties of SPA

\begin{tabular}{|c|c|c|c|}
\hline Economic & Social Facilities & Achievement & Meeting Needs \\
\hline $\begin{array}{l}\text { Buying flowers, pastry and } \\
\text { small presents for teachers on } \\
\text { special days such as teachers' } \\
\text { day. } \\
\text { Creating funds for school } \\
\text { Helping the students who are } \\
\text { in need financially }\end{array}$ & $\begin{array}{l}\text { Organizing social activities such } \\
\text { as travel, end of year events, } \\
\text { charity events, campaign; } \\
\text { Working for school } \\
\text { development }\end{array}$ & $\begin{array}{l}\text { Working to increase the } \\
\text { student achievement } \\
\text { Working to improve the } \\
\text { status of educational } \\
\text { activities in school }\end{array}$ & $\begin{array}{l}\text { Improving the physical } \\
\text { infrastructure of the student (Doing } \\
\text { repairs, meeting the physical needs } \\
\text { of school) } \\
\text { Meeting school's cleaning and } \\
\text { equipment needs. }\end{array}$ \\
\hline
\end{tabular}

It seems that the work of SPA mostly direct at improving the quality education. This improvement is in favour of teachers, students and school environment and the aim is to improve the system for the student. 


\subsection{The Efficiency of SPA}

The teachers thought that SPA is inefficient. Table 3 presents why the work of SPA can be inefficient.

When Table 3 is examined, except for one teacher, all teachers think that the work of SPA is inefficient and ineffective. This may be because the participation in high school SPAs is less than the participation of parents in primary school SPAs. When asked about the reasons for ineffectiveness of the SPA, it is possible to categorize them as characteristics of the parents, viewpoints and communication. The opinions of the participants in these categories are given below.
- I do not think SPA is working effectively. There is little dialogue between school and parents. There is no effective communication. No one wants to take responsibility at school and this is the main problem (Ahmet).

- $\quad$ Our parents see this task as a big burden They do not want to be involved. But it was different in the past when we ad parents with more awareness. Now I think it's not that effective (Bilge).

- I don't think it's done effectively. The reason SPA is ineffective is because... well I'm actually going to be a little bit critical in this sense. I think that we will get more different results if families are involved in any planning, for example in a meeting (Ecesu).

Table 3. Reasons for inefficient SPA

\begin{tabular}{|c|c|c|}
\hline \multicolumn{3}{|c|}{ Reasons for Ineffective SPA work } \\
\hline Parent-related reasons & View Points & Communication \\
\hline $\begin{array}{l}\text { Insufficient capacity of the parents } \\
\text { Parent's own work } \\
\text { Less participation of parents } \\
\text { Indifferent parenting } \\
\text { Parents who may be beneficial for the } \\
\text { SPA are avoiding meetings } \\
\text { No one wants to be in control of the } \\
\text { school }\end{array}$ & $\begin{array}{l}\text { The idea that people will be asked to donate money in the } \\
\text { meetings } \\
\text { The idea that association only deals with money, income } \\
\text { and expenses } \\
\text { The idea that the association is a unit that only does approval } \\
\text { Feeling nervous about the commitments } \\
\text { Feeling reluctant to engage with event such as trip or } \\
\text { financial resources that generate income for the school. } \\
\text { Seeing the school work as burden and unnecessary } \\
\text { Reluctant to take responsibility }\end{array}$ & $\begin{array}{l}\text { Lack of effective communication } \\
\text { Parents are not aware of the } \\
\text { importance of SPA } \\
\text { Parents are not included in the } \\
\text { facilities of the school }\end{array}$ \\
\hline
\end{tabular}

As seen Table 3, parents can be a source of the ineffective work of SPA, but some reasons also concern teachers and principals. The lack of communication is mainly related to the teachers and managers. Overcoming or minimizing this barrier may increase participation

\subsection{The Profile of Parents on SPA}

The profile of parents who participated in SPA based on the responses of teachers are presented in Table 4.

Table 4. The profile of parents who participated in SPA

\begin{tabular}{ll}
\hline \multicolumn{1}{c}{ According to the student profile } & \multicolumn{1}{c}{ According to the Characteristics of Parent } \\
\hline The parents of successful students & The parents who have good social skills \\
The parents of students who do not have disciplinary problems & The parents with low-level of education \\
The parents of students who are appreciated by their teachers and peers & Women parents \\
The parents of primary and secondary school students & The parents who want to take responsibility at school \\
& The parents who come to school regularly \\
& Middle-income parents \\
& The parents who have worked in SPA before \\
& The parents who want to monitor their students' progress \\
& The parents who want to establish close relationships with \\
& teacher \\
& The parents with sense of responsibility \\
& The parents who prioritise education of their children \\
\hline
\end{tabular}


As seen in Table 4, the profile of students can be categorised according to their characteristic and to the profile of their children. Some quotations of participants are presented below.

- We see that parents who come to school regularly to monitor their students' progress participate more in the meetings. There are parents who do not monitor their children's progress but still attend the meeting and take this as an opportunity to have an idea of their children's performance. The middle-income parents attend more and sometimes we see that that mothers who are in employment attend (Mehmet).

- $\quad$ The parents who participate in SPA are those whose children are successful and do not have any discipline problems. Parents mostly do not attend these meetings because they see them as a burden. Those who want to be in the management of the SPA are those who took part a role in primary and secondary school SPA managements before (Salih).

- The parents who have high achieving students are members of SPA. The parents of students who are unsuccessful usually do not attend meetings. Parents who do not want to make donation do not participate.
SPA is seen as an institution that asks money from parents. That is how parents see it (Yusuf).

Parents who have sense of responsibility, with middle-income and good social relations and whose children are successful usually attend the meetings. This may be because these parents want to have a say in their children's education and want to learn what is going on at school.

\subsection{Increasing Participation of Parents to SPA}

Teachers indicated that participation in SPA activities are at a very low level and the reasons for this are presented in Table 5.

The low participation was categorised under responsibility, economic reasons and other reasons and quotations of the participants are presented below:

- Parents' full-time employment or the idea that SPA members will ask money may be the reasons why there is low participation (Ali).

- Parents think they will be assigned with responsibilities, or they will need to donate money. We do not do such things in our school (Bilgen).

Table 5. Reasons for low participation in SPA

\begin{tabular}{llc}
\hline \multicolumn{1}{c}{ The idea that they will be assigned responsibility } & Economic Reasons & Other reasons \\
\hline $\begin{array}{l}\text { Parents see SPA as a burden } \\
\text { They are uncomfortable with the amount of workload to be }\end{array}$ & $\begin{array}{l}\text { The idea that they will be asked for } \\
\text { money }\end{array}$ & $\begin{array}{l}\text { Full time employment of } \\
\text { parents } \\
\begin{array}{l}\text { Feeling reluctant to take responsibility } \\
\text { Feeling reluctant to chair the meetings and take responsibility }\end{array}\end{array}$ \\
\hline
\end{tabular}

When these reasons were examined, it was seen that participants frequently mentioned that parents see SPA as a burden. In addition, the idea that parents will be asked to donate money and previous negative experiences can be expressed as obstacles to the participation of parents. Based on this, the teachers were asked what should be done to increase participation and Table 6 presents some of the answers.

Table 6. What needs to be done to increase parent participation

\begin{tabular}{ll}
\multicolumn{1}{c}{ Communication } & \multicolumn{1}{c}{ Including in management and activities } \\
\hline $\begin{array}{l}\text { Deconstructing the idea that they will need to donate money } \\
\text { Deconstructing the idea that students will be blamed for } \\
\text { negativities }\end{array}$ & $\begin{array}{l}\text { Increasing the awareness among parents to participate in the } \\
\text { management } \\
\text { Assigning responsibilities to parents in activities (trips etc) } \\
\text { Ensuring that parents will not be the only responsible }\end{array}$ \\
\cline { 2 - 2 } $\begin{array}{l}\text { Informing parents about the meeting though text messages } \\
\text { Parent visits, }\end{array}$ & $\begin{array}{l}\text { Meeting } \\
\text { Organising activities that could attract parents to school, } \\
\text { Not using students as messengers } \\
\begin{array}{l}\text { Direct communication with parents } \\
\text { Counselling service seminars }\end{array}\end{array}$ \\
$\begin{array}{l}\text { Displaying the activities on the website } \\
\text { weekends }\end{array}$ \\
\hline
\end{tabular}


As seen in Table 6, teacher suggested to increase communication, explain the importance of the SPA and include parents in management and meetings. Quotations are provided below:

- We need to call parents or ask them to pass the message to their parents in order to increase the participation. We should visit families at home (Ilke).

- To increase participation, we first need to deconstruct the idea that SPA is a burden. Parents also think that they will be asked money if they attend the meeting. This idea also needs to be deconstructed. Usually students are asked to tell their parents that there will be SPA meeting but they do not necessarily tell this to their parents.

- I think if seminars are delivered to students and parents, their interest in SPA may increase. This is how it is done in private schools (Mehmet).

Communicating with parents, planning activities that can attract them to school, including them in facilities and making them feel important, and organising the meetings at a time that parents can attend may increase their participation in SPA meetings and events.

\subsection{The Suggestions to Make SPA More Active and Effective}

These suggestions are categorised under three headings: actions that need to be taken by (a) Ministry of National Education, (b) principals and teachers, and (c) parents. Table 7 presents the actions that need to be taken by Ministry of National Education (MoNE).

The first category (a) of the initiatives that should be taken by principals and teachers are presented in Table 8 . As seen Table 7, teachers indicated that MoNE should pass legal regulations, provide professional manager infrastructure, set up legal support commission, give up money-raising understanding, make community services mandatory, ensure a legislation that makes money raising legal and appreciate the work of SPA members and teachers. The views of participants are presented below:

- $\quad$-First of all, MoNE will lead the initiatives. They will work on the legal infrastructure. If necessary, they should frequently announce legal regulations or sub-directives. SPAs are not established to generate income for schools; their duties are community services, organise cultural trips, theatres. Firstly, MoNE should lead and perform these duties (Mehmet)

- $\quad-M o N E$ should be more responsible on this matter. There should be a legal regulation, the work of teachers and parents should be appreciated (Ilke).

Table 7. Actions need to be taken by MoNE (a)

\begin{tabular}{l}
\hline \multicolumn{1}{c}{ What should MoNE do? } \\
\hline Legal regulation \\
Professional manager infrastructure support \\
Setting up legal support commissions and giving up money-raising understanding \\
Making community services, cultural trips, theatre, etc. mandatory \\
Making money-raising legal and compulsory \\
Appreciating the work of PAT members and teachers
\end{tabular}

The second category (b) of the initiatives that should be taken by principals and teachers are presented in Table 8 .

Table 8. The actions and initiatives that should be taken by principals and teachers (b)

What should principals and teachers do?

\footnotetext{
Guidance services should work actively, and organise seminars, conferences and so on etc.

Family visits should be increased

Parent should not feel nervous when they come to school,

Activities should be organized to ensure solidarity

Establishing corporate culture

Establishing a sense of trust towards SPA members

Participation in the meetings should be encouraged

Communicating with parents (message, phone call)

The importance of SPA work should be explained to teachers and parents.

All teachers should be actively involved in the work,

SPA expenditures should be transparent

The time and place of SPA meetings should be adjusted so that parents can participate easily

Meritocracy should be in place when selecting managers.
} 
As seen above, Table 8 lists several actions that principals and teachers should be attentive to and some quotations are provided below:

- SPA members must be freed from the monetary burdens loaded to them in the regulation. At least one professional manager should be selected to be active in their meetings if necessary. Teachers should be actively involved in these associations. School counselling services should be more active. School-parent-social integration should be ensured. Regular family visits should be made. The parents should not feel nervous when they come to school. Activities should be organized to ensure solidarity. Cultural trips should be organized. Corporate culture should be established (Ali)

- School Administrators should ensure that they trust SPA members. Parents should be on the field. Parents should recognize SPA members and establish dialogue (Ahmet).

- Parents should be encouraged to attend meetings. Communication should be ensured either via message or in person. The importance of SPA work should be explained to teachers. Teachers are reluctant to attend these meetings. The expenditures of the SPA should be transparent. The time and place of the SPA meetings should be arranged so that parents can participate easily (Salih).

The third category (c) of the actions and initiatives that SPA members should take are as follows: Parents should recognize the SPA members and have a dialogue; SPA members should be supported by parents, parents should be convinced for management roles, memberships should not be on paper and members should work actively.

- $\quad$ The parents who see other parents being involved in SPA meetings can feel encouraged. If they become part of SPA meetings, a family environment can be formed. What we need at this stage is the parents. Parents play an important role in achievement. In our school, we do not have parent participation (Ecesu).

- In order to make SPA work more effective, it is necessary to include parents who want to work and who volunteer for it. SPA is not only an admin work, SPA members should come to our school, be active in our school activities. We do not see a SPA activity in our school, there are very few participants involved in it. But if the parents who are dedicated to education are recruited, then things could be different (Ilke).

The promotion of SPA activities and showing what is done for the school can increase participation. The association can only be successful with the collaboration of teachers, principals, parents and the ministry.

\section{Conclusions, Discussion}

This research shows that the majority of the participants do not know exactly who the members of SPA are. Likewise, Kandemir [25] concludes that parents and teachers don't have much idea about the SPA and the duties of the SPA. In Kebeci's [27] research, about half of the teachers stated that they knew something about the SPA, but not enough. Quarter of them said that they did not know anything about the SPA and the rest stated that they have full knowledge.

The work SPA members do for school can be listed as; activities to provide financial resources for teachers, school and students; social activities; activities to meet social needs, to increase student's academic achievement and to improve the physical environment. Genc [20] states that the SPA meets at least once a year and they discuss the needs of the school, the activities to provide income for school and the student achievements in these meetings. In Ozdemir's [41] study, SPA expenditures were identified as staff expenses and payments, maintenance and repair of information technology, maintenance of the building, purchases of cleaning material, stationary expenses and financial assistance to poor students. Dogru [17] concluded that the SPA was involved into school management for financial matters. Koc [32] found that the SPA focused more on the need for physical environment, equipment and academic achievement; however, it did not do much in terms of social-cultural activities and charity activities for students in need.

The results of the study show that teachers think the work of SPA is ineffective. The reasons for this are listed as lack of parent participation, parent characteristics, parents' negative ideas about SPA and lack of communication. Bingol [6] states that SPAs do not fulfill their duties adequately. Ceylan and Akar [10] argues that cooperation between school and parent is partially sufficient but teachers have high expectations.

Kincal [28] concludes that the communication between teachers and parents is very limited and the parents do not make any effort to cooperate, which prevents school-parent cooperation. Ozgan and Aydin [42] states that SPAs do not fulfil their duties and responsibilities adequately and as a result SPAs remains as an association on paper and inactive. Kiransal [31] argues that according to the opinions of teachers, SPAs cannot fulfil duties adequately. Likewise Ictin [26] states that SPA activities in high schools have not been realized at the desired level. Cakir [13] advocates that SPAs are necessary but not functional in current structure. In the study of Erdogan [18], participants think that the contribution of the SPA is moderate in improvement of the school and school-parent-student relations. Akbasli [1] concludes that the majority of parents do not show interest in the SPA. According to Baylan [4], SPAs fulfil only their financial duties. Henderson and Mapp [23] reach a conclusion that families can improve their children's academic performance and they can have a major impact on student's behaviour.

Results of the research show that parents of successful 
students with no disciplinary problems attend the meetings. The research of Unal, Yildirim and Celik [47] concluded that principals and teachers perceived some parents as unconscious, indifferent, not knowing what was good for their children, uncollaborative with the school, and instinctively protecting their children. In a study conducted by Ozgan and Aydin [42], teachers indicated that parents came to school when there were problems, and they did not give enough support to school and teachers. Kebeci [27] found that majority of the members of PTA were with primary level of education

According to participants' opinions, there is the lack of participation in the activities of SPA due to economic reasons. In a study by Ozgan and Aydin [42], principals and teachers believed that school and parents should support each other in the education of child, but parents did not attend the meetings due to fear of being asked for money. Erdogan and Demirkasimoglu's [19] research on the participation of parents in education process showed that negative attitudes of educators, negative attitudes of parents and insufficient knowledge or education level of parents were the most important obstacles for participation.

According to Cakir's [13] research, income level as socio-economic and demographic characteristics, education level of parents and number of children affect parents' participation were the reasons for low participation. In Baeck's [5] study, parents' participation in cooperation with school varied according to parents' educational level. Parents' education level stimulated an obstacle for participation because parents who had low levels of education felt insecure about their knowledge of academic issues.

Communication, deconstruction of prejudices, explaining the importance of the SPA, including parents into meetings and management duties can increase the participation of parents. Cakir's [13] research showed that communication, social activities and family visits could be effective in order to increase family participation. Yavuz [48] concluded that to strengthen school-family cooperation, use of information technology can have a positive effect on teachers, parents, school management and students. The results of Sheldon and Epstein's [46] research show that more linkages and greater cooperation between school, family and community contexts can be a way for schools to improve student behaviour and school discipline.

Things to be done to increase parental participation are divided into three categories: Ministry of National Education, principals and teachers, and parents. "What Ministry of National Education should do?" can be categorised under legal regulation, infrastructure to support principals, establishing legal support commissions and giving up money collecting, making travel and theatre activities compulsory, and appreciating SPA members and teachers for their work and contribution.

Participants stated that there is a need to focus on active work of principals and teachers, increasing the family visits, and addressing parents' fear of coming to school. Ozgan and Aydin [42] state that single agenda meetings can be organized to present the structure and purpose of SPA and SPA members should be recruited among active and enthusiastic individuals. In the research of Erdogan and Demirkasimoglu [19], principals and teachers agree on the necessity of family visits. Gokce's [21] research reached a conclusion that demands, and request of parents should be taken into consideration, social activities should be increased, and SPA should be functional.

Participants mentioned that member parents of SPA should be introduced to rest of parents and should stimulate a dialogue between each other in order to get support of other parents. According to Erdogan and Demirkasimoglu's [19] research, teachers want parents to come to the school more frequently and regularly, and to learn about their children's progress and to participate in parent-teachers meetings.

The work of SPA can be explained to all stakeholders of the school, especially the teachers; therefore, everyone can actively participate in work of the association. Teacher members of SPA can be appreciated, and the legal framework can be organized accordingly. To increase participation of parents, different communication paths can be used such as; family visits, SMS and phoning parents. In addition to that, parents' seminars and trainings can be organized, and these organizations can be dinner organizations to improve participation. The same research can be conducted using quantitative methods.

\section{REFERENCES}

[1] Akbasli, S. (2007). Task accomplishment level of parent-school partnership at secondary schools Doctoral Dissertation, Hacettepe University, Ankara.

[2] Aslan, M., Ozer, N. \& Bakir, A. A. (2009). Administrators' and Teachers' Views on School Culture: A Qualitative Study. Elementary Education Online, 5(1), 268-281.

[3] Aslanargun, E. (2007). The Review of Literature on School-Parent Cooperation and Students' School Success. Manas University Journal of Social Studies, 18, 119-135.

[4] Baylan, M. (2008). The level of fulfillment of the family-school union functions according to school administrators. Master Thesis. Yeditepe University, Istanbul.

[5] Baeck, U. D. K. (2010). Parental involvement practices in formalized home-school cooperation. Scandinavian Journal of Educational Research, 54(6), 549-563.

[6] Bingol, C. (2004). Defining the degree of school-parent associations' doing duties. Master Thesis. Yildiz Techinical University, Istanbul.

[7] Bush, T. (2009). The Principles of Educational Leadership 
and Management, London: Sage Publications.

[8] Can, N. (2011). Factors Affecting the School Organization, K. Keskinkilic (Ed.), Turkish Education system and School Management (in 229-280). Ankara: Pegem Akademi.

[9] Can, N. (2013). Role Playing in School Management. N. Can (Ed.), Educational Administration: Theory and Practices. (in 155-182). Ankara: Pegem Akademi.

[10] Ceylan, M., \& Akar, B. (2010). Evaluation of Teachers' and Parents' Views on School-Family Cooperation in High Schools. Cankırı Karatekin University Journal of Institute of social sciences, 1(2), 43-64.

[11] Christenson, S. L. \& Reschly, A. L. (Eds.). (2010). Handbook of school-family partnerships. Routledge.

[12] Creswell, J. W. (2016). Qualitative inquiry and research design choosing among five approaches. M. Butun \& S. B. Demir (Trans.Edt.). Ankara: Siyasal.

[13] Cakir, E. (2017). Evaluation of the opinions of principals intended for parental participation in middle schools. Master Thesis, Necmettin Erbakan University, Konya.

[14] Celenk, S. (2003). The prerequisite for school success: Home-school cooperation. Elementary Education Online, 2(2), 28-34.

[15] Dam, H. (2008). The Family Factor on the Student's Success of School. Journal of Divinity Faculty of Hitit University, 7(14), 75-99.

[16] Demirtas, H. (2008). Human rights and democracy education. Journal of Education, 20, 54-20.

[17] Dogru, C. T. (2005). The Effect of school-teacher-family cooperation to the classroom management. Master Thesis. Zonguldak Karaeelmas University, Zonguldak.

[18] Erdogan, M. (2017). The research is to understand the contribution of ptas to the development of public schools and to conduct research on tools on how to improve the administiration. Master Thesis, Okan University, Istanbul.

[19] Erdogan, C. \& Demirkasimoglu, N. (2010). Teachers' and School Administrators' Views of Parent Involvement in Education Process. Educational Administration: Theory and Practice, 16 (3), 399-431.

[20] Genc, S. Z. (2005). Elementary school-family cooperation in the 1st level teachers and parents. Journal of Turkish Education sciences, 3(2), 227-243.

[21] Gokce, E. (2000). Development of School Family Cooperation. Pamukkale Universitesi The Journal of Turkish Educational Sciences 7, 204-209.

[22] Helvac1, M. A. \& Aydogan, I. (2011). A Study on the Perceptions of Teachers on the Qualities of Effective School and School Principal. Usak University Journal of Social Sciences, 2011(8).

[23] Henderson, A. T. \& Mapp, K. L. (2002). A New Wave of Evidence: The Impact of School, Family, and Community Connections on Student Achievement. Annual Synthesis.

[24] Ictin, A. (2013). Opinions of principals of Anatolian high schools and public high schools, teachers and parent-school partnership managers about Administrative Functions of the
Parents-school partnership. Master Thesis. Hasan Kalyoncu University, Gaziantep, Turkey.

[25] Kandemir, E. (2010). Problems faced in the function of parent teacher associations at primary schools. Master Thesis, Erciyes University, Kayseri.

[26] Kartal, S. (2008). The Participation of Parents in Primary and Secondary School Management. Ahi Evran University Journal of Kirsehir education Faculty, 9(1), 23-30.

[27] Kebeci, S. (2006). The role of parent teacher association on school performance. Master Thesis, Marmara University, Istanbul.

[28] Kincal, R. Y. (1991). The process of realizing the functions of school family cooperation. Doctoral Dissertation. Ataturk University, Erzurum.

[29] Kiral, B. \& Kiral, E. (2009). The Perceptions of Parents of the Students on the Qualifications of Human Rights and Democracy Education in Elementary Schools. International Congress on Intercultural Dialogue and Education Human Beings, Society, Intercultural Dialogue and Education at the beginnings of the 21 st Century.

[30] Kiral, B. (2017). School community relations. M. M. Arslan (Ed.).Turkish education system and school management. (in 299-356). Ankara: Soysal.

[31] Kiransal, N. (2007). The relation between school and family in primary education. Master thesis, Kafkas University, Kars.

[32] Koc, M. H. (2010). Investigation of institutions in the finance of elementary schools parent-teacher association model. Master Thesis, Gazi University, Ankara.

[33] Kocak, Y. (1991). Barriers to school-family communication. Hacettepe University Journal of Faculty of Education, 6(6).

[34] Martin, J., Tett, L., \& Kay, H. (1999). Developing collaborative partnerships: limits and possibilities for schools, parents and community education. International Studies in Sociology of Education, 9(1), 59-75.

[35] Merriam, S. B. (2013). A guide to qualitative research design and implementation. S. Turan (Tr.Ed.). Ankara: Nobel.

[36] Miles, M. B. \& Huberman, A. M. (1994). Qualitative data analysis. Thousand Oak: Sage.

[37] Ministry of National Education 3rd. National Education Council. (02-10 December 1946). https://ttkb.meb.gov.tr/meb_iys_dosyalar/2017_09/2916464 6_3_sura.pdf

[38] Ministry of Education, Basic Law of National Education (1973). Official gazette date and number: 24.06.1973 and 1739.

[39] Ministry of Education the Regulation of the School Parent Association. (2012). Official gazette date and number: 09.02.2012 and 28199

[40] Nayir, F. (2018). School - Family - Environment Relations. U. Akin (Edt.). Turkish Education system and School management. (in 366-381). Ankara: Pegem Akademi.

[41] Ozdemir, N. (2011). A tool for primary education financing: Analysis of Parent Teacher Associations budget. Master 
Thesis. Hacettepe University, Ankara.

[42] Ozgan, H. \& Aydin, Z. (2010). Administrator, teacher and parent views on school-family cooperation. $9^{\text {th }}$ National Symposium fo Classroom Teacher Training, 20-22.

[43] Patton, M. Q. (2014). Qualitative Research \& Evaluation Methods. M. Butun \& S. B. Demir (Tr. Eds.). Ankara: Pegem Akademi.

[44] Patrikakou, E. N. \& Anderson, A. R. (Eds.). (2005). School-family partnerships for children's success. Teachers College Press.

[45] Saritas, M. (2011). School administration and transaction, K. Keskink1lıc (Ed.), Turkish Education system and School management. (in 145-195). Ankara: PEGEM Akademi.

[46] Sheldon, S. B. \& Epstein, J. L. (2002). Improving student behavior and school discipline with family and community involvement. Education and urban society, 35(1), 4-26.

[47] Unal, A., Yildirim, A. \& Celik, M. (2010). Analysis of Perceptions of Primary School Principals and Teachers About Parents. Selcuk University the Journal of Institute of Social Sciences, 23, 261-272.

[48] Yavuz, A. (2014). Effect of using the information technology on increasing school parent cooperation within the vocational schools : A comparative study. Master Thesis. Afyon Kocatepe University, Afyonkarahisar.

[49] Yildirim, N. (2013). School Improvement, S. Ozdemir (Ed.), Educational Administration: Theory and Practice. (in 229-280). Ankara: Pegem Akademi.

[50] Yildirim, C. M. \& Donmez, B. (2008). A study on school-family cooperation. e-Journal of social sciences, 7(23), 98-115.

[51] Yildirim, A. \& Simsek, H. (2005), Qualitative research methods in the social sciences. Ankara: Seckin.

\footnotetext{
i This study is an improved version of the paper presented at Vth International Eurasian Educational Research Congress in 2018 at Antalya Akdeniz University in Turkey.
} 